\title{
Groundwater Quality Assessment for Irrigation Purposes in the West of Minia, Governorate, South Egypt ${ }^{\text {b }}$ \\ Hegazi, I. M. ${ }^{\text {; } ~ M . ~ H . ~ H . ~ A b b a s ~}{ }^{2}$; A. O. A. Ismail ${ }^{1}$ and Ghada A. Abdel-Kader \\ ${ }^{1}$ Soil, water and Environment Institute \\ ${ }^{2}$ Soils and Water Department, Faculty of Agric. Benha Univ.
}

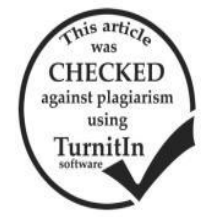

\section{ABSTRACT}

This investigation has been conducted to assess the suitability of ground waters in west Minia governorate for irrigation purposes. Thirty-three groundwater samples were collected from different sites, along Assiut the West Desert Road. These samples were analyzed for water quality criteria, namely electrical conductivity (EC), soluble cations $\left(\mathrm{Ca}^{2+}, \mathrm{Mg}^{2+}, \mathrm{Na}^{+}\right.$and $\left.\mathrm{K}^{+}\right)$, anions $\left(\mathrm{HCO}_{3}^{-}, \mathrm{CO}_{3}^{2-}\right.$, $\mathrm{Cl}^{-}$and $\mathrm{SO}_{4}{ }^{2-}$ ). The chemical parameters that control water quality such as sodium adsorption ratio (SAR), soluble sodium percent (SSP\%), residual sodium carbonated (RSC), Kelley's ratio (KR), potential salinity (PS), permeability index (PI), total alkalinity, total hardness, magnesium ratio were also calculated using standard equations. Results revealed that anions contents in the studied ground waters followed the sequence: $\mathrm{SO}_{4}{ }^{2-}>\mathrm{Cl}^{-}>\mathrm{HCO}_{3}{ }^{-}$whereas $\mathrm{CO}^{-3}$ ion was not detected. On the other hand, the cations contents of the water samples followed the sequence: $\mathrm{Na}^{+}>\mathrm{Mg}^{2+}>\mathrm{Ca}^{2+}>\mathrm{K}^{+}$. In addition, the $\mathrm{pH}$ values of the studied water samples ranged between 6.9 and 7. 9. The analytical results indicated that $94 \%$ of the groundwater samples can be classified as good for irrigation on bases of EC, SAR, RSC and SSP\%. Both SAR and RSC values indicated no liability for sodicity hazard. However, groundwater samples had high salinity levels and low sodicity (C3-S1). Some other parameters, which were generally used for assessing water quality e.g. Irrigation Water Quality Index (IWQI) and Relative Crop Yield Potential (RCYP), were calculated. GIS was used to create a water quality database including spatial distribution map for each parameter. The results obtained herein showed that about $21 \%$ of the groundwater samples belong to No Restriction category (NR) while about $79 \%$ from the total samples belong to the Low Restriction (LR) category. According to the RYPC values calculated for some crops that can be cultivated using the investigated waters, the following sequence is obtained: sugar beet (94) > wheat (74) > corn (33) > bean (13). Thus, it can be concluded that the studied groundwater can successfully be used for irrigation with special salinity control management i.e. leaching requirements and salt tolerant plants.

Keywords: Groundwater, Chemical characters, Irrigation water quality, assessment, relative yield and GIS maps.

\section{INTRODUCTION}

Water is a critical natural resource for human life sustainability on the earth. In Egypt, intensive agricultural activities have increased the demand for irrigation water. Therefore, groundwater resources are considered the third water resource for irrigation purpose, after the River Nile and drainage water. Physicochemical quality of water is necessary to evaluate its suitability for different usages. Quality of ground water depends on natural processes i.e. dissolution and precipitation of minerals, as well as recharge of water and its interaction with other water types (Andrade $e t$ al., 2008). The natural chemical quality of groundwater depends on the concentrations of a number of constituents which may cause problems for soil or plant on the long term. Hydrogeochemical processes of groundwater are influenced by various factors, such as rock-water interaction and human activities (Hounslow, 1995). Many factors decide the rate of suitability of water for irrigation, e.g. water quality, soil type, salt tolerance characteristics of plants, climate and drainage (Appelo and Postma 2005 and Jafaret al., 2013). Sodium adsorption ratio (SAR) and residual sodium carbonate (RSC) are the most important factors of quality criteria, which have high influence on water suitability for irrigation (USSL, 1954).

The integration of the geographic information system (GIS) platform to the assessment procedure not only allows the decision maker to create parameter maps for easy visual interpretation but also makes the overall analysis more sound, objective and simple (Waqed 2014). Water Quality Index (WQI) is a very useful and efficient method to evaluate the suitability of water quality and for communicating the information on overall quality of water (Asadiet al., 2007). The determination of WQI helps in deciding the suitability of groundwater sources for its intended purpose. From the early 1960s, different WQI methods have been developed (Horton 1965; Harkins 1974).

This work aims at assessing the suitability of some groundwaters in west Minia governorate for irrigation purpose. It will also employ the WQI proposed by Tiwari and Mishra (1985) in assessing the quality of the studied groundwater samples to identify its suitability for agricultural purpose and to produce maps of the groundwater quality as well as relative yield maps for some crops.

\section{MATERIALS AND METHODS}

Samples of groundwater were taken from $33 \mathrm{dug}$ wells during March 2017 in different sites of the study area which represent about $28 \mathrm{~km} 2$ (Fig. 1). Water samples were collected in polyethylene bottles prewashed with $1: 1 \mathrm{HCl}$ and rinsed several times with the same groundwater samples. The bottles were tightly closed, labeled and transported to the laboratory and filtered through $0.45-\mu \mathrm{m}$ cellulose membranes on the same day and then stored at $4 \mathrm{C}^{\circ}$. Acidity number $(\mathrm{pH})$ and electrical conductivity (EC) were measured in site immediately after collecting the samples using portable field meters. The chemical analyses of the different samples were carried out using the standard methods described by APHA (1995). Total hardness and calcium were determined by ethylene-diamine-tetra-acetic acid titrimetric method. Magnesium was estimated by difference between total hardness and calcium. Total alkalinity, carbonate, bicarbonate, and chloride were estimated using titrimetric methods. Sodium and potassium were estimated by flame photometer. Sulphate was determined by gravimetrically method. Total dissolved solids, RSC, \% soluble sodium, SAR, Kelley's ratio (KR), permeability index (PI), total alkalinity and magnesium ratio were calculated using standard equations. Thirty-three surface soil samples were taken from the same sites of groundwater and analyzed for soil acidity $(\mathrm{pH})$, electrical conductivity (ECe), saturation percent (SP) and particle size distribution and results are presented in Table 3. The analytical data were then used to assess the suitability of ground water samples for irrigation.

Calculation of Irrigation Water Quality index IWQI

Values of $\mathrm{EC}, \mathrm{Na}^{+}, \mathrm{Cl}^{-}, \mathrm{HCO}_{3}^{-}$and Sodium Absorption Ratio (SAR) parameters have been selected tocalculate the water quality index (IWQI) model developed by Meireleset al. (2010) according to the following equation: 


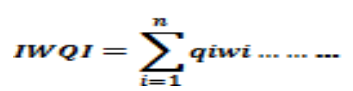

Equation 1

Where: IWQI is irrigation water quality index, $\left(q_{i}\right)$ is the quality of the parameter and $\left(w_{i}\right)$ values are the weights of the considered parameters. The criteria of parameters are recognized by Ayers and Westcot (1985) (Table 1). qiwas calculated using the next equation depending on the tolerance limits according to Meireleset al. (2010) $q i=q i \max -\{(X i j-X i n f) * q i a m p) / /_{X} a m p \quad$ Equation 2

Where: qimaxis the maximal value of qi for the category, xijis the parameter spotted value, xinfis the value corresponding to the minimal limit of the category to each parameter, qiampis the category amplitude, xampis the category ampleness of each parameter.

The weight values (wi) of each chemical parameter used in the quality index of irrigation water have been suggested by Meireleset al. (2010). The limitations of the water classes are proposed after computing the total index values are presented in Table 2.

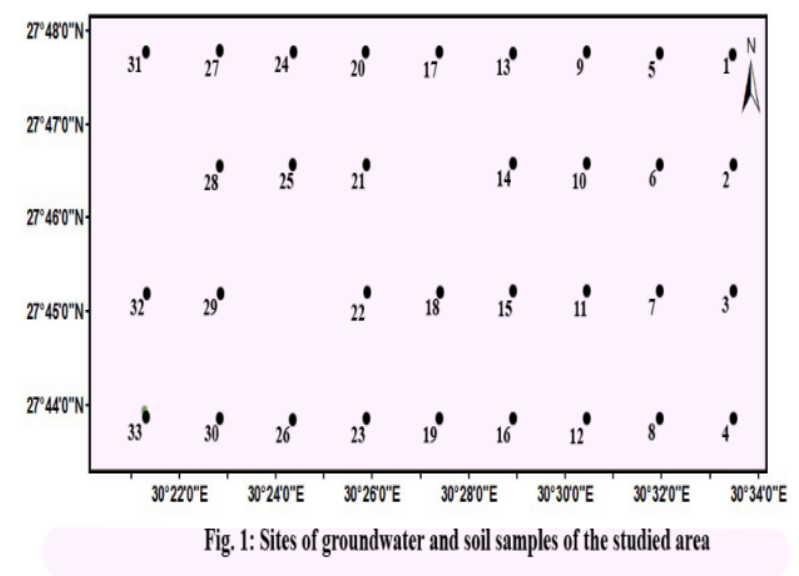

Table 1. Critical limits values of parameters and its classes for quality index (qi)

\begin{tabular}{|c|c|c|c|c|c|}
\hline \multirow[b]{2}{*}{$\mathbf{q}_{\mathbf{i}}$} & \multicolumn{3}{|c|}{ Ion } & \multirow{2}{*}{ SAR } & \multirow{2}{*}{$\mathrm{EC}(\boldsymbol{\mu S} / \mathbf{c m})$} \\
\hline & $\mathrm{HCO}_{3}^{-}$ & $\mathrm{Cl}^{-}$ & $\mathbf{N a}^{+}$ & & \\
\hline $85-100$ & $1 \leq \mathrm{HCO}_{3}<1.5$ & $1 \leq \mathrm{Cl}<4$ & $2 \leq \mathrm{Na}^{+}<3$ & $2 \leq \mathrm{SAR}<3$ & $200 \leq \mathrm{EC}<750$ \\
\hline $60-85$ & $1.5 \leq \mathrm{HCO}_{3}<4.5$ & $4 \leq \mathrm{Cl}^{-}<7$ & $3 \leq \mathrm{Na}^{+}<6$ & $3 \leq \mathrm{SAR}<6$ & $750 \leq \mathrm{EC}<1500$ \\
\hline $35-60$ & $4.5 \leq \mathrm{HCO}_{3}^{-}<8.5$ & $7 \leq \mathrm{Cl}^{-}<10$ & $6 \leq \mathrm{Na}^{+}<9$ & $6 \leq \mathrm{SAR}<12$ & $1500 \leq \mathrm{EC}<3000$ \\
\hline $0-35$ & $\begin{array}{l}\mathrm{HCO}_{3}<1 \text { or } \\
\mathrm{HCO}_{3}^{-} \geq 8.5\end{array}$ & $1<\mathrm{Cl}^{-} \geq 4$ & $\begin{array}{l}\mathrm{Na}^{+}<2 \\
\mathrm{Na}^{+} \geq 9\end{array}$ & $2 \leq \mathrm{SAR} \geq 12$ & $\begin{array}{c}\mathrm{EC}<200 \\
\mathrm{EC} \geq 3000\end{array}$ \\
\hline \multicolumn{6}{|c|}{ Parameters weight by Meireleset al. (2010) } \\
\hline Weight & 0.221 & 0.204 & 0.202 & 0.194 & 0.189 \\
\hline
\end{tabular}

Table 2. Characteristics of Irrigation Water Quality Index (based on Meireleset al., 2010)

\begin{tabular}{|c|c|c|c|}
\hline IWQI & $\begin{array}{l}\text { Water use } \\
\text { restriction }\end{array}$ & & Recommendation \\
\hline
\end{tabular}

85-100 $\begin{gathered}\text { No } \\ \text { restriction }\end{gathered} \quad$ No toxicity risk for most plants $\quad \begin{aligned} & \text { May be used for the majority of soils with low probability of } \\ & \text { causing salinity and sodicity problems, being recommended } \\ & \text { leaching within irrigation practices, except for in soils with }\end{aligned}$

leaching within irrigation practices, except
extremely low permeability

\begin{tabular}{ccc}
\hline $70-85$ & $\begin{array}{c}\text { Low } \\
\text { restriction }\end{array}$ & Avoid salt sensitive plants \\
\hline $55-70$ & $\begin{array}{c}\text { Moderate } \\
\text { restriction }\end{array}$ & $\begin{array}{c}\text { Plants with moderate tolerance to salt } \\
\text { may be grown }\end{array}$ \\
\hline 40-55 & $\begin{array}{c}\text { High } \\
\text { restriction }\end{array}$ & $\begin{array}{c}\text { Should be used for irrigation of plants with } \\
\text { moderate to high tolerance, to salts with } \\
\text { special salinity control practices expect } \\
\text { water with low Na, } \mathrm{Cl} \text { and } \mathrm{HCO}_{3} \text { values }\end{array}$ \\
\hline 0-40 & $\begin{array}{c}\text { Severe } \\
\text { restriction }\end{array}$ & $\begin{array}{c}\text { Only plants with high salt tolerance } \\
\text { except for waters with extremely low } \\
\text { values of } \mathrm{Na}, \mathrm{Cl} \text { and } \mathrm{HCO}_{3}\end{array}$ \\
\hline
\end{tabular}

The values of IWQI of water suitability for irrigation categories have been divided into five categories varying from (0 to 100) and it is dimensional parameter. The categories were divided depending on the proposed groundwater quality index, which was set by the existing groundwater quality indices. They have been defined on bases of salinity hazard problems, soil infiltration, as well as toxicity to plants as noticed in the different classes suggested by Holanda and Amorim (1997).

\section{The Relative Crop Yield Potential (Y)}

The equation proposed by Maas and Hoffman (1977) was used to calculate the relative crop yield that can be achieved under salinity threshold value. The yield is presented as percentage of the same crop in absence of salinity stress:

$$
\mathbf{Y}=\mathbf{1 0 0}-\mathbf{b}\left(\mathbf{E C}_{\mathrm{e}}-\mathbf{a}\right) \quad \text { Equation } 3
$$

Where "Y": is the relative crop yield (percent), "EC the soil saturation extract in $\mathrm{dSm}^{-1}$, "a" is the salinity threshold value and " $b$ " is the yield loss per unit increase in salinity. The values for (a) and (b) were given by Maas (1990) in his original paper but can also be determined.
Recommended for use in irrigated soils with light texture or moderate permeability, being recommended salt leaching. Soil sodicity in heavy texture soils may occur, being recommended to avoid its use in soils with high clay

May be used in soils with moderate to high permeability values, being suggested moderate leaching of salts

May be used in soils with high permeability without compact layers. High frequency irrigation schedule should be adopted for water with EC above $2000 \mu \mathrm{S} \mathrm{cm}^{-1}$ and SAR above 7.0

Should be avoided its use for irrigation under normal conditions. In special cases, may be used occasionally. Water with low salt levels and high SAR require gypsum application. In high saline content water soils must have high permeability, and excess water should be applied to avoid salt accumulation

The (a) value (the threshold soil salinity) is the $\mathrm{EC}_{\mathrm{e}}$ value for 100 percent yield potential. The (b) value can be determined as follows:

$\mathrm{b}=100 /\left(\mathrm{EC}_{\mathrm{e}}\right.$ at zero \% yield $-\mathrm{EC}_{\mathrm{e}}$ at $100 \%$ yield $)$

\section{RESULTS AND DISCUSSION}

\section{Groundwater Chemistry pH values}

Results of the physico-chemical analyses of the groundwater samples Table 3 reveal that $\mathrm{pH}$ of the ground water samples ranged from neutral to slightly and moderately alkaline and varied from 7.3 to 8.0 with an average of 7.55. These values indicate that the dissolved carbonates are predominant as $\mathrm{HCO}_{3}{ }^{-}$form (Adams et al. 2001). The lowest $\mathrm{pH}$ value (7.3) was recorded for sample No. 1, whereas the highest value was recorded for sample No. 15. All the samples lie within the permissible range of (pH 6.5 - 8.4) according to Ayers and Westcot (1985). Therefore, the groundwater samples are suitable for 
irrigation purposes without any potential dangerous effect on soil or plant. Sutharsinyet al. (2012) mentioned that $\mathrm{pH}$ of groundwater typically ranges from about 6.5 to 8.5, depending on soil type and rock that has reacted with the groundwater. These values seem almost be coincide with those reported herein for the studied groundwater samples.

\section{Water salinity}

EC values of the groundwater samples varied from 0.77 to $2.49 \mathrm{dSm}^{-1}$ with an average of $1.17 \mathrm{dSm}^{-1}$. The minimum value is shown for the sample No. 28 while the maximum one is noticed for the sample No. 22 (Table 3). This variation in EC values can be attributed to lithology variation (Zenget al., 2016), rate of evaporation (Aragüéset al., 2015), weathering and amount of recharge (Sulieman et al., 2016). In other words, groundwater salinity may be affected by salts dissolved from soil and materials of aquifer, and salts leached from irrigation, (Ayers and Westcot, 1985 and Deshpande and Aher, 2012). Bauder et al. (2007) has classified the groundwater samples depending on EC to the following classes $<250 \mu \mathrm{S} / \mathrm{cm}$ excellent, 251-750 $\mu \mathrm{S} / \mathrm{cm}$ good, 751-2000 $\mu \mathrm{S} / \mathrm{cm}$ permissible, 2001-3000 $\mu \mathrm{S} / \mathrm{cm}$ doubtful and $>3000 \mu \mathrm{S} / \mathrm{cm}$ unsuitable. According to this classification, $97 \%$ of the water samples belong to the permissible class, while about $3 \%$ belongs to a doubtful group, which is represented by the sample no. 22 only, Table 3 . On the other hand, according to Freeze and Cherry (1979) and Liu et al. (2017) the groundwater samples are classified according to total dissolved salts into brackish (TDS $>1,000 \mathrm{mgL}^{-1}$ ) and fresh (TDS $<1,000 \mathrm{mgL}^{-1}$ ). Thus $6 \%$ of the groundwater samples belong to the brackish class and $94 \%$ belongs to the freshwater class, (Table 3).

Table 3. Chemical properties of the ground water and soil samples

\begin{tabular}{|c|c|c|c|c|c|c|c|c|c|c|c|c|c|c|c|c|c|}
\hline \multirow{3}{*}{ WS } & \multirow{2}{*}{\multicolumn{2}{|c|}{ Coordinates (m) }} & \multicolumn{10}{|c|}{ Groundwater samples } & \multirow{3}{*}{$\underset{\mathbf{m g L}^{-1}}{B}$} & \multirow{2}{*}{\multicolumn{4}{|c|}{ Soil }} \\
\hline & & & \multirow{2}{*}{ pH } & \multirow{2}{*}{$\underset{\mathbf{d S m}^{-1}}{\mathbf{E C}}$} & \multirow{2}{*}{$\begin{array}{c}\text { TDS } \\
\text { mgL }^{-1}\end{array}$} & \multicolumn{4}{|c|}{ Cations mmolcL $^{-1}$} & \multicolumn{3}{|c|}{ Anions mmolcL ${ }^{-1}$} & & & & & \\
\hline & North & East & & & & $\mathrm{Ca}^{2+}$ & $\mathbf{M g}^{2+}$ & $\mathrm{Na}^{+}$ & $\mathbf{K}^{+}$ & $\mathrm{HCO}_{3}^{-}$ & $\mathrm{Cl}^{-}$ & $\mathrm{SO}_{4}{ }^{2-}$ & & $\mathbf{p H}$ & ECe & SP & Text \\
\hline 1 & 259602 & 3077876 & 7.3 & 0.92 & 588 & 2.11 & 2.46 & 3.91 & 0.09 & 2.08 & 2.13 & 4.37 & n.d. & 7.7 & 3.5 & 28 & SL \\
\hline 0 & 238403 & & 7.4 & 0.94 & 601 & 2.64 & 2.06 & 3.83 & 0.09 & 1.98 & 2.38 & 4.26 & & 7.8 & 4.4 & 27 & SL \\
\hline & & & 5 & 0.99 & 633 & 2.7 & 2.95 & 4.09 & 0.09 & 1.89 & 2.25 & 5.69 & n.d. & 8.1 & 3.7 & 23 & LS \\
\hline 4 & & & 5 & 1.15 & 736 & 2.49 & 2.36 & 5.13 & 0.09 & 1.7 & 3 & 5.37 & & 8.0 & 12.7 & 30 & SL \\
\hline 5 & 239741 & 674 & 7.4 & 1.21 & 774 & 2.72 & 2.54 & 5.39 & 0.09 & 1.6 & 3.44 & 5.7 & n.d. & 8.0 & 12.3 & 23 & LS \\
\hline & & & & 1.44 & 921 & 3.34 & 2.75 & 6.8 & 0.11 & 1.51 & 4.06 & 7.42 & n.d. & 7.9 & 5.8 & 24 & LS \\
\hline 1 & & & 6 & 1.41 & 902 & 3.11 & 3.11 & 6.2 & 0.09 & 1.32 & 3.88 & 7.3 & n. & 7.8 & 6 & 25 & LS \\
\hline 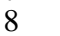 & 2456 & & 7.6 & 1.13 & 723 & 2.62 & 2.27 & 5.13 & 0.09 & 1.32 & 3.13 & 5.67 & n.d. & 7.9 & 7.7 & 25 & LS \\
\hline & & & & 1.18 & 755 & 3.15 & 1.89 & 5.3 & 0.11 & 1.79 & 3.38 & 5.29 & n. & 8.1 & 5.9 & 26 & SL \\
\hline 10 & & & 7.5 & 1.35 & 864 & 3.51 & 1.97 & 6 & 0.11 & 1.6 & 4 & 5.98 & $\mathrm{n}$. & 8.0 & 4.1 & 23 & LS \\
\hline 11 & & & 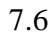 & 1.12 & 716 & 2.72 & 2.15 & 5.3 & 0.11 & 2.17 & 3.13 & 4.99 & & 8.2 & 21.2 & 30 & SL \\
\hline & & & & 1.67 & 1068 & 4.36 & 2.81 & 7.6 & 0.13 & 1.32 & 5 & 8 & & 7.8 & 6 & 25 & LS \\
\hline 13 & & & 7.7 & 1.23 & 787 & 3.3 & 2.12 & 5.48 & 0.12 & 1.6 & 3. & 5.9 & & 8.0 & 10.7 & 30 & SL \\
\hline & & & 7.6 & & 915 & 3.62 & 2.93 & 6.6 & 0.11 & 1.42 & 4 & 7.8 & & 8.0 & 38.7 & 22 & LS \\
\hline 15 & & & 0 & & 915 & 3.94 & 2.15 & 7 & 0.11 & 1.7 & 4 & 7. & . & 7.9 & 10.3 & 25 & LS \\
\hline 16 & & & 7.7 & 1.2 & 787 & 3.28 & 1.79 & 5.83 & 0.09 & 1.1 & 3.25 & 6.0 & $\mathrm{n}$. & 8.0 & 10.3 & 24 & LS \\
\hline & & & & & 710 & 2.77 & 1.8 & 5.3 & 0.09 & 1.79 & 2.88 & 5.2 & & 7.9 & 6.9 & 27 & SL \\
\hline 18 & & & 7 & 1 & 806 & 3.17 & 2.24 & 5.57 & 0.11 & 16 & 3.25 & 6.2 & . & 8.5 & 17.4 & 26 & SL \\
\hline 19 & & & 7.7 & 0.97 & 620 & 2.45 & 1.53 & 4.7 & 0.1 & 1.79 & 2.5 & 4.4 & $\mathrm{n}$. & 8.0 & 5.1 & 27 & SL \\
\hline & & & & & & 6 & 1.19 & 4.52 & 0.09 & 1.75 & 2.25 & 4. & & 8.2 & 22.6 & 22 & LS \\
\hline 1 & & & 1 & 0 . & 627 & 2.98 & 1.33 & 4.78 & 0.09 & 1.89 & 2. & 4.7 & $\mathrm{n}$. & 8.0 & 3.7 & 20 & $\mathrm{~S}$ \\
\hline & & & 7 & & 1593 & 2.49 & 1.49 & 4.87 & 0. & 1.89 & 2. & 4. & & 8.0 & .4 & 23 & LS \\
\hline & & & & & & 2.55 & 2.29 & 5.13 & 0. & 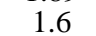 & 2.88 & $\approx$ & & 7.9 & & 25 & LS \\
\hline 24 & & & 7.4 & & 569 & 2.04 & 1.57 & 4.61 & 0.07 & 1.65 & 2.25 & 4.3 & & 8.0 & 3.2 & 22 & LS \\
\hline 25 & & & & & 5 & 2.21 & 0.83 & 4.87 & 0. & 1. & ? & 4.6 & & 8.1 & 3.8 & 26 & SL \\
\hline 26 & & & & & & . & & 142 & & & 2 & & & 84 & & 23 & SCL \\
\hline 27 & & & 7.5 & 0 . & 569 & 1.57 & 2.01 & 4.52 & 0.13 & 1.42 & 1.88 & 4. & & 8.4 & 6.8 & 33 & SCL \\
\hline 28 & & & & & 49 & 2. & 2.14 & 3.48 & 0.1 & 1.9 & 1.75 & 4. & 0. & 8.4 & 13.4 & 28 & SL \\
\hline 0 & & & & & & 2.55 & 2.8 & 3. & 0 & 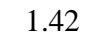 & 1 & 6. & & 8.4 & 13.4 & 28 & SL \\
\hline 30 & & & 5 & 1.2 & 812 & 2.26 & 3.33 & 5.65 & 0.14 & 1.6 & 3.13 & 5.6 & & 7.9 & 10.7 & 34 & SCL \\
\hline 31 & & & & 0.7 & 499 & 1.7 & 2.56 & 3.74 & 0 . & 1.51 & 2 & 4.5 & & 7.9 & 10.7 & 25 & LS \\
\hline 32 & & & 7 & & 819 & 3.15 & 3.22 & 5.39 & 0.1 & 1. & 3. & 7.1 & & 8.0 & 36.4 & 31 & SCL \\
\hline 33 & 238213 & 3070218 & 7.5 & 1.36 & 870 & 2.49 & 3.03 & 6.6 & 0.14 & 1.32 & 3.5 & 7.44 & n.d. & 8.0 & 6.0 & 25 & LS \\
\hline
\end{tabular}

WS=Water samples; EC=Electrical conductivity; TDS=Total dissolved salts; SP=Saturation percent; Text=Texture class; LS=Loamy sand; SL=Sandy loam; $S C L=$ Sandy clay loam

\section{Soluble Ions}

Table 3 shows that the concentrations of $\mathrm{Ca}^{2+}$, $\mathrm{Mg}^{2+}, \mathrm{Na}^{+}$and $\mathrm{K}^{+}$ions ranged from 1.57 to $4.36,0.83$ to $33.3,3.48$ to 7.6 , and 0.07 to $0.14 \mathrm{mmol}_{\mathrm{c}} \mathrm{L}^{-1}$ with average values of $2.67,2.24,5.2$, and $0.1 \mathrm{mmol}_{\mathrm{c}} \mathrm{L}^{-1}$, respectively. About $75.7 \%$ of the soluble cations of the water samples could be arranged in the following descending order $\mathrm{Na}^{+}>$ $\mathrm{Ca}^{2+}>\mathrm{Mg}^{2+}>\mathrm{K}^{+}$, while in $24.3 \%$ of the water samples, the soluble cations followed the sequence: $\mathrm{Na}^{+}>\mathrm{Mg}^{2+}>\mathrm{Ca}^{2+}>$ $\mathrm{K}^{+}$. The dissolved anions $\mathrm{HCO}_{3}^{-}, \mathrm{Cl}^{-}$and $\mathrm{SO}_{4}{ }^{2-}$ ranged between 1.32 to $2.17,1.75$ to 5.0 and 4.26 to 8.58 mmol $_{\mathrm{c}} \mathrm{L}^{-1}$ with average values of $1.63,2.93$ and $5.71 \mathrm{mmol}_{\mathrm{c}} \mathrm{L}^{-1}$, respectively. All anions of the groundwater samples could be arranged in the following descending order: $\mathrm{SO}_{4}{ }^{2-}>\mathrm{Cl}^{->}$ $\mathrm{HCO}_{3}{ }^{-}$. Carbonate ions are not found in any detectable concentration in the investigated water samples.

\section{Soluble Sodium Percentage (SSP)}

Arshidet al. (2011) mentioned the high amount of sodium in irrigation water is considered undesirable because it can be potentially adsorbed on the exchange sites causing dispersion of soil aggregates, thereby lower soil permeability. The sodium in irrigation waters may be also expressed as soluble sodium percentage (SSP) and it is calculated using the formula proposed by Wilcox (1955) and Bunani et al. (2005), where all ionic concentrations are expressed in $\mathrm{mmol}_{\mathrm{C}} \mathrm{L}^{-1}$.

$$
\mathbf{N a} \%=\frac{(\mathrm{Na}+\mathrm{K})}{(\mathrm{Ca}+\mathbf{M g}+\mathbf{N a}+\mathrm{K})} * \mathbf{1 0 0} \quad \text { Equation } 4
$$

According to Wilcox (1955), the water samples are grouped depending on SSP into: Excellent $(<20 \%)$, good (20-40\%), permissible (40-60\%), doubtful (60-80\%) and unsuitable $(>80 \%)$. Data in Table 4 reveal that, the 
highest SSP value $(61.9 \%)$ was recorded for the sample number 25 , while the lowest $(42.5 \%)$ was recorded for the sample number 2. About $97 \%$ of the ground water samples are classified as permissible according to their SSP values, while $3 \%$ of the groundwater samples are doubtful for irrigation. SSP are taken against electrical conductivity values and are designated as Wilcox diagram in Fig. (2). The soils irrigated with water sample no. 22 must receive leaching requirement and cultivated with salt tolerant plants like beet, sorghum and others according to Sutharsinyet al. (2012).

Table 4. The parameters used for evaluating water quality

\begin{tabular}{|c|c|c|c|c|c|c|c|c|c|}
\hline WS & SAR & $\mathbf{R}$ & SSP & KR & $\begin{array}{l}\mathrm{Ca} / \mathrm{Mg} \\
\text { molar }\end{array}$ & $\begin{array}{c}\mathrm{Ca} / \mathrm{Mg} \\
\text { ratio }\end{array}$ & PS & PI & $\begin{array}{r}\text { Adj } \\
\text { SAR }\end{array}$ \\
\hline 1 & 2.59 & 0.46 & 46.70 & 0.86 & 0.86 & 46.20 & 4.32 & 62.50 & 4.30 \\
\hline 2 & 2.50 & 0.42 & 45.50 & 0.81 & 1.28 & 56.20 & 4.51 & 60.80 & 4.20 \\
\hline 3 & 2.43 & 0.33 & 42.50 & 0.72 & 0.92 & 47.80 & 5.10 & 55.60 & 4.00 \\
\hline 4 & 3.30 & 0.35 & 51.80 & 0.97 & 1.06 & 51.30 & 5.69 & 63.90 & 5.10 \\
\hline 5 & 3.32 & 0.30 & 51.00 & 0.96 & 1.07 & 51.70 & 6.29 & 62.00 & 5.30 \\
\hline 6 & 3.90 & 0.25 & 53.20 & 1.12 & 1.21 & 54.80 & 7.77 & 61.80 & 5.90 \\
\hline 7 & 3.52 & 0.21 & 50.30 & 0.98 & 1.00 & 50.00 & 7.54 & 58.70 & 5.30 \\
\hline 8 & 3.28 & 0.27 & 51.60 & 0.97 & 1.15 & 53.60 & 5.97 & 62.10 & 5.00 \\
\hline$y$ & 3.34 & 0.36 & 51.80 & 0.96 & 1.67 & 62.50 & 6.03 & 63.50 & 5.70 \\
\hline 10 & 3.63 & 0.29 & 0 & 0.97 & 1.78 & 64.10 & 6.99 & 62.70 & 5.70 \\
\hline 11 & 3.40 & 0.45 & 52.60 & 0.99 & 1.27 & 55.90 & 5.625 & 65.90 & 5.70 \\
\hline 12 & 4.01 & 0.18 & 51.90 & 0.98 & 1.55 & 60.80 & 9.29 & 58.70 & 6.80 \\
\hline 13 & 3.33 & 0.30 & 50.80 & 0.96 & 1.56 & 60.90 & 6.455 & 61.20 & 5.30 \\
\hline 14 & 3.65 & 0.22 & 50.60 & 0.97 & 1.24 & 55.30 & 7.92 & 58.80 & 5.80 \\
\hline 15 & 4.01 & 0.28 & 53.90 & 1.15 & 1.83 & 64.70 & 7.75 & 62.90 & 6.66 \\
\hline 16 & 3.66 & 0.34 & 53.90 & 1.15 & 1.83 & 64.70 & 6.27 & 64.90 & 5.90 \\
\hline 17 & 3.51 & 0.39 & 54. & 1.16 & 1.54 & 60.60 & 5.53 & 66.60 & 5.50 \\
\hline 18 & 3.38 & 0.30 & 51.20 & 0.97 & 1.42 & 58.60 & 6.37 & 61.60 & 5.60 \\
\hline 19 & 3.33 & 0.45 & 54.70 & 1.18 & 1.60 & 61.60 & 4.74 & 68.80 & 5.10 \\
\hline 20 & 3.26 & 0.45 & 54.50 & 1.17 & 2.24 & 69.10 & 4.485 & 69.10 & 5.00 \\
\hline 21 & 3.26 & 0.44 & 53.10 & 1.11 & 2.24 & 69.10 & 4.90 & 67.00 & 4.90 \\
\hline 22 & 3.45 & 0.47 & 55.60 & 1.22 & 1.67 & 62.60 & 4.785 & 69.70 & 5.20 \\
\hline 23 & 3.30 & 0.33 & 51.80 & 0.98 & 1.11 & 52.70 & 5.67 & 63.70 & 5.20 \\
\hline 24 & 3.43 & 0.46 & 56.50 & 1.28 & 1.30 & 56.50 & 4.45 & 71.10 & 5.30 \\
\hline 25 & 3.95 & 0.43 & 61.90 & 1.60 & 2.66 & 72.70 & 4.34 & 75.40 & 5.10 \\
\hline 26 & 3.01 & 0.35 & 51.20 & 0.96 & 1.16 & 53.80 & 4.7 & 63.50 & 4.50 \\
\hline 27 & 3.38 & 0.40 & 5650 & 1.26 & 0.78 & 43.90 & 4.35 & 69.40 & 4.90 \\
\hline 28 & 2.36 & 0.35 & 45.30 & 0.80 & 1.03 & 50.80 & 4.09 & 59.20 & 3.56 \\
\hline 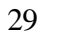 & 2.37 & 0.26 & 42.70 & 0.72 & 0.89 & 47.00 & 4.97 & 53.90 & 3.90 \\
\hline 30 & 3.38 & 0.29 & 50.90 & 0.96 & 0.68 & 40.40 & 5.96 & 60.80 & 6.20 \\
\hline 31 & 2.56 & 0.35 & 47.40 & 0.88 & 0.66 & 39.90 & 4.30 & 61.30 & 3.80 \\
\hline 32 & 3.02 & 0.25 & 46.50 & 0.85 & 0.98 & 49.50 & 6.72 & 55.90 & 4.90 \\
\hline 33 & 3.97 & 0.24 & 55.00 & 1.20 & 0.82 & 45.10 & 7.22 & 63.20 & 5.60 \\
\hline
\end{tabular}

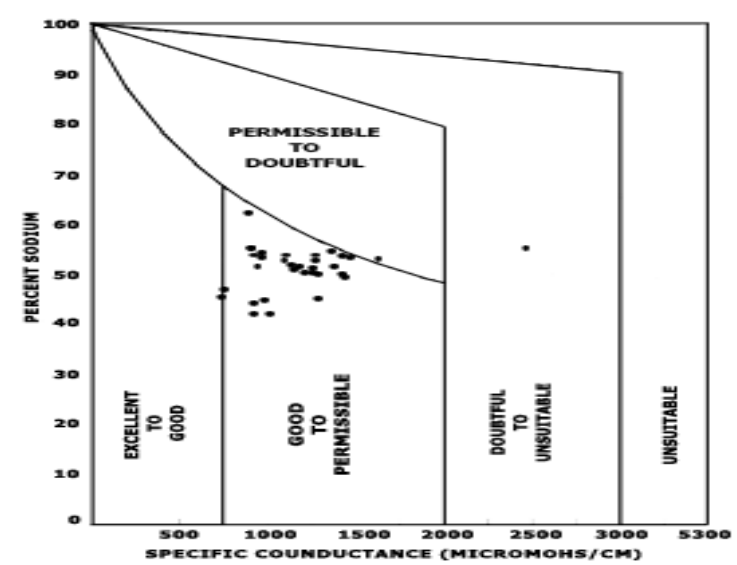

Fig. 2. Groundwater samples rating to salinity and percent of soluble sodium percent(SSP)

\section{Sodium Adsorption Ration (SAR)}

Sodium adsorption ratio (SAR) is a more reliable approach for determining the effect of relative cation concentrations to sodium accumulation in the soil than sodium percentage. The groundwater samples are classified according to SAR value as follows: < 10 excellent, 10-18 good, 18-26 doubtful and > 26 unsuitable (USSL, 1954). (SAR) is calculated with the following formula, where all ionic concentrations are expressed in $\operatorname{mmol}_{\mathrm{C}} \mathrm{L}^{-1}$.

$$
\operatorname{sAR}=\frac{\mathrm{Na}}{\sqrt{\mathrm{Ca}+{ }^{\mathrm{MI} / 2}}}
$$

Equation 5

Values of SAR are shown in Table 4 and the minimum and maximum values of SAR are 2.36 and 4.01, respectively, Table (4). All the studied water samples (100\%) are classified, therefore, as excellent water, where these groundwater samples have SAR values less than 10. These water samples are suitable for irrigation without any dangers of exchangeable sodium on either soil or plant (USSL 1954).

\section{Salinity and Alkalinity Classes}

According to USSL (1954) salinity and alkalinity classes, water samples are highly saline with low sodicity (C3-S1), except the sample, no. 22 that has very high salinity and low SAR (C4-S1) Fig., (3). This means that the groundwater samples cannot be used as a source for irrigation without special conditions for salinity control such as application of the water-leaching requirement, adequate drainage and selected salt tolerant plants. La uchli and Epstein (1990) pointed out that water salinity has undesirable effect on plant growth by different ways, such as osmotic pressure, specific ion toxicity and nutritional disorders.

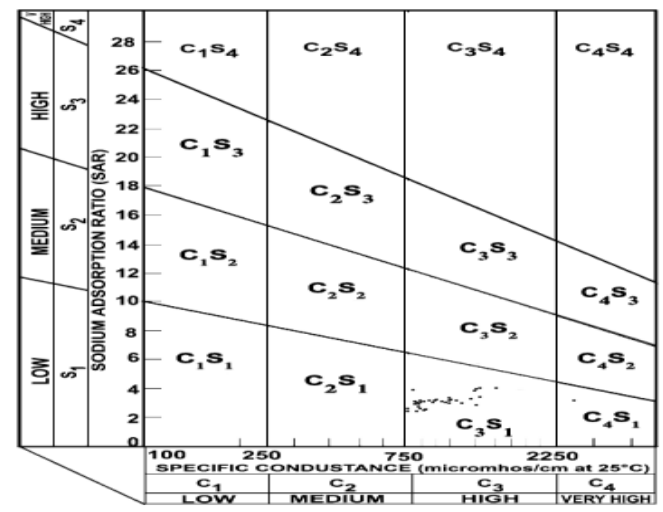

Fig. 3. Groundwater samples rating to electrical conductivity and sodicity hazard

Residual Sodium Carbonate (RSC)

Residual sodium carbonate (RSC) has been calculated to determine the hazardous effect of carbonate and bicarbonate on water quality. It is determined by the following equation according to Prasad et al. (2001) RSC $=(C O 3+\mathrm{HCO3})-$ $(\mathrm{Ca}+\mathrm{Mg})$, where ions concentrations are expressed in mmol $_{\mathrm{c}} \mathrm{L}^{-1}$.Generally, when water has excess concentration of bicarbonate there will be tendency for calcium and magnesium to precipitate as carbonates. Table 4 shows that the values of RSC ranged from 0.184 to 0.475 mmol $_{c} \mathrm{~L}^{-1}$ with an average of $0.34 \mathrm{mmol}_{\mathrm{c}} \mathrm{L}^{-1}$. Based on RSC values, the studied groundwater samples are less than $1.25 \mathrm{mmol}_{\mathrm{C}} \mathrm{L}^{-1}$ and can be considered good for irrigation purposes.

\section{Kelly's Ratio}

Kelly (1940) has determined the hazardous effect of sodium on water quality for irrigation usage in terms of Kelly's ratio (KR). It means the ratio of sodium to calcium and magnesium ions computed as:

$$
K R=\frac{N a}{C a+M g}
$$

\section{Equation 6}

$\mathrm{KR}$ varied from 0.72 to 1.6 with an average value of 0.98 . A Kelley's ratio (KR) of more than one indicates an excess of sodium level in waters and unsuitable for irrigation, while the value of a Kelley's ratio less than one 
is suitable for irrigation. The results obtained herein indicate that $63.6 \%$ of Kelley's ratio (KR) values for the groundwater samples under study area are equal or less than 1 which means that 63.6 of the investigated groundwater samples are of good quality for irrigation purpose, while $36.4 \%$ recorded KR values more than 1 which indicates that they are of unsuitable quality for irrigation (Table 4). Generally the mean KR value of water samples is (0.98) indicating that most of the ground water samples are suitable for irrigation purpose as their average $\mathrm{KR}$ values is less than 1 .

\section{The permeability Index (PI)}

The soil permeability is influenced by several soil cations such as sodium, calcium and magnesium as well as bicarbonate anions. Raghunath (1987) and Aghazadeh and Mogaddam (2014) suggested a criterion for assessing suitability of water quality for irrigation based on permeability index (PI) and classified it into three classes: I and II are categorized as good and suitable classes for irrigation with $75 \%$ or more maximum permeability. Class III is unsuitable with $25 \%$ maximum permeability.

$$
P I=\frac{N a+\sqrt{H C O 3}}{\mathrm{Ca}+\mathrm{Mg}+\mathrm{Na}} * 100
$$

Equation 7

The concentrations of ions are in $\mathrm{mmol}_{\mathrm{c}} \mathrm{L}^{-1}$. The PI values range from 53.9 (sample No. 29) to 75.4 (sample No. 25 ) with an average value of 63.2, (Table 4). Data revealed that about $58 \%$ and $42 \%$ of the studied water samples are subjected to the first and second classification, respectively, and they are good and suitable for irrigation.

\section{Magnesium hazard}

In most waters, there is an equilibrium status between calcium and magnesium but when dolomites prevail and/or in some case of soils of marine origin, magnesium prevails resulting in adverse effects on both soil and crop yields, Arvetiet al. (2016). The excessive amounts of dissolved magnesium in irrigation water are thought to be coupled with soil permeability problems, Kushalet al., (2015). Magnesium hazard is assessed by following equations, firstly magnesium ratio $\left\{(\mathrm{Ca} /(\mathrm{Ca}+\mathrm{Mg}))^{*} 100\right\}$ and secondly calcium to magnesium molar $(\mathrm{Ca} / \mathrm{Mg})$.

Data presented in Table 4, show that the magnesium ratio varied from 39.9 to $72.7 \%$ with an average value of $55.6 \%$. About $75.7 \%$ of total samples, relatively, have $\mathrm{Mg}$ ratio values more than $50 \%$, which may adversely affect the crop yield according to Paliwal (1972). Ca:Mg molar values ranged from 0.66 to 2.66 with an average of 1.34. About $75 \%$ of total samples showed Ca:Mg molar ratio > 1and are considered as good water class according to Jalali (2008) and Kushal et al., (2015) who pointed out that water with a $\mathrm{Ca}: \mathrm{Mg}$ molar ratio $<1$, resulted in increases of SAR values, which adversely affect soil structure and crop yield.

\section{Chloride (Cl)}

Chloride is a good indicator of groundwater quality and it is also considered an essential element for plant growth. The minimum and maximum contents of $\mathrm{Cl}^{-}$in the studied samples are 1.75 and $5 \mathrm{mmol}_{\mathrm{c}} \mathrm{L}^{-1}$, respectively (Table 3). According to Ayers and Westcot (1985), the groundwater samples can be classified into three groups, according to their contents of chloride, as follows: suitable $\left(\mathrm{Cl}<4 \operatorname{mmol}_{\mathrm{C}} \mathrm{L}^{-1}\right)$, marginally $\left(4-10 \quad \operatorname{mmol}_{\mathrm{c}} \mathrm{L}^{-1}\right)$ and unsuitable $\left(\mathrm{Cl}>10 \mathrm{mmol}_{\mathrm{C}} \mathrm{L}^{-1}\right)$, thus about $85 \%$ of water samples which have $\mathrm{Cl}^{-}$contents of less than 4 mmol $_{\mathrm{c}} \mathrm{L}^{-1}$ being belong to the suitable group. Moreover, and according to Mass (1990) who reported that levels of chloride between 140 and $350 \mathrm{mgL}^{-1}$ are injurious to even moderately tolerant plants and those of $350 \mathrm{mgL}^{-1}$ may cause severe damage to plant life, consequently about $82 \%$ of the investigated samples are suitable for irrigation since their chloride concentrations are less than $140 \mathrm{mgL}^{-1}$.

\section{Boron (B)}

Boron content in water is considered an important indicator for evaluating its suitability for irrigation. According to the guidelines suggested by Ayers and Westcot (1985), slight to moderate degree of restriction occurs only if $\mathrm{B}$ content in the irrigation water exceeds $0.7 \mathrm{mg} \mathrm{B} \mathrm{L}^{-1}$. The results obtained herein presented very low concentrations of $\mathrm{B}$ in the water samples i.e. $\leq 0.06 \mathrm{mg} \mathrm{B} \mathrm{L}^{-1}$ and therefore no problems with boron can be deduced in such waters. Moreover, these waters can be used safely for irrigating very sensitive crops $\left(<0.5 \mathrm{mg} \mathrm{B} \mathrm{L}^{-1}\right)$ according to Ayers and Westcot (1985).

\section{Assessment of Irrigation Water Quality Index (IWQI) Quality Index (qi)}

Quality index of the used parameter is calculated according to "California University Committee of Consultant (UCCC)" by Ayers and westcot (1985) as follows:

$q i=\operatorname{qimax}-\{(x i j-x i n f) * q i a m p\} / x a m p \quad$ Equation 8

According to Meireleset al. (2010), the qi value was classified to four classes as follow; class 1 has value of qi from 100 to 85 , class 2 from 85 to 60 , class 3 (60 to 35) and class 4 (less than 35).

The quality index $\mathrm{q}_{\mathrm{i}}$ calculated for the EC parameter, The quality index qi calculated for the EC parameter, as presented in Table 5, varied between 43.5 and 84.3 (belong to the second and third classes 6 and $94 \%$, respectively). Quality index values of SAR, SSP, $\mathrm{Cl}$, and $\mathrm{HCO} 3-$ are ranged between 76.6 to $93.6,51.7$ to $81,76.3$ to 93.6 , and 79.4 to 90.4 , respectively. These indicated that qi values for $\mathrm{SAR}, \mathrm{Cl}$, and $\mathrm{HCO} 3$ representing the first and second classes and, thus these samples are considered suitable for irrigation from this point of view. While the qi values of SSP belong to the second and third classes, therefore, more attention is needed for soil leaching requirements.

\section{Irrigation Water Quality Index (IWQI)}

Irrigation Water Quality Index (IWQI) is an important parameter for assessing groundwater quality (Avvannavar and Shrihari, 2008).

According to Meireleset al. (2010), the IWQI is classified to 5 classes as follows: IWQI which has values from 85 to 100 is considered of no restriction, while that which has values ranging from 70 to 85 is of low restriction, and IWQI of values ranging from 55 to 70 is considered of moderate restriction while that of values ranging from 40 to 55 is considered of high restriction whereas that of values ranging from 0 to 40 is considered of severe restriction, Table (2). According to the IWQI values of the groundwater samples, obtained values ranged from 73.1 to 85.7 (Fig and Table, 5). The water samples are belonged either to the first category or to the second ones, and they are either of no restriction or at least of low restriction class. The water of the first category is safe and suitable irrigating most plants; while of the second category, (low restriction) may cause problems for salt sensitive plants and therefore be used in irrigation on light textured and moderately permeable soils with salt leaching. 

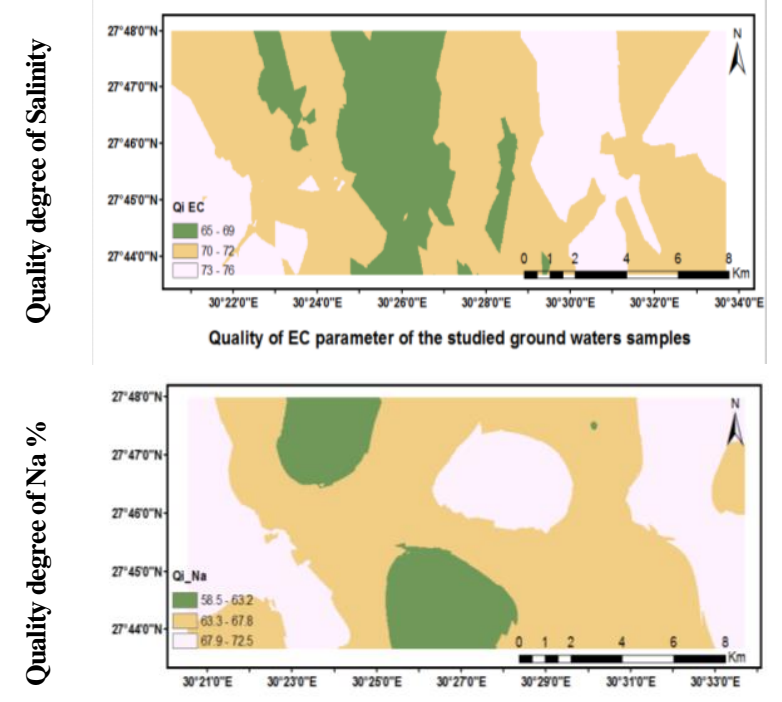

Quality of Na parameter of the studied ground waters samples
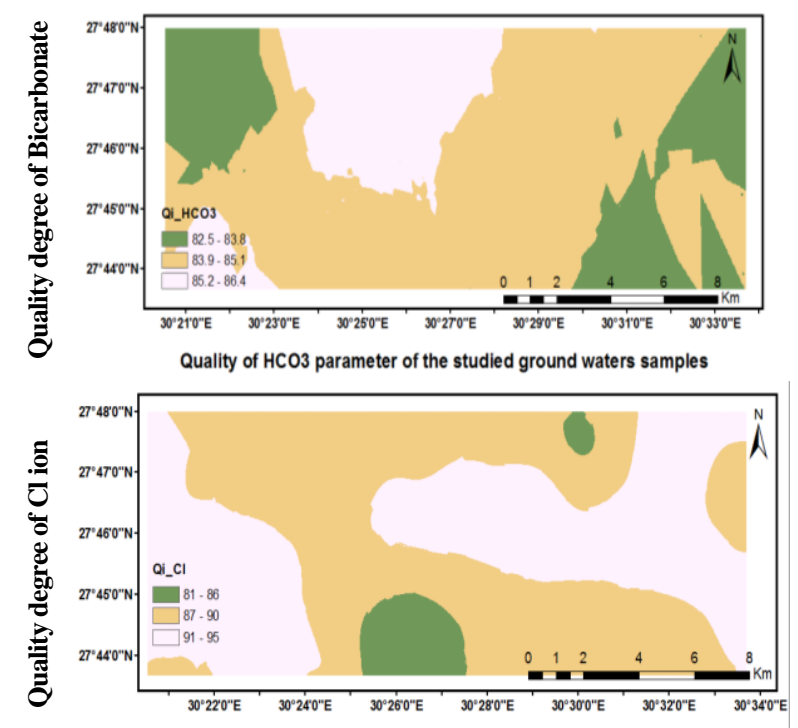

Quality of $\mathrm{Cl}$ parameter of the studied ground waters samples

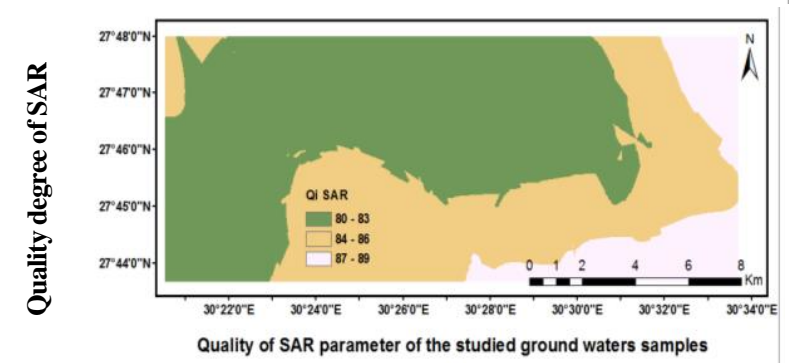

Fig. 4. Water quality of the studied samples according to different water parameters

Fig. 6 represents the relative yield potential maps of selected crops such as bean, corn, and sugarbeet as well as wheat crops based on Hoffman equation. The values of relative yield potential for bean ranged from 0.0 to $58 \%$ with an average of $13 \%$, Table (6). According to the calculated values of (RYPC) for bean crop, about $58 \%$ of the investigated groundwater samples have zero value, i.e., will not give any bean yield when used for irrigation. About $36 \%$ of these water samples may result in relative yield potential for bean less than $50 \%$, whereas two samples $(1 \& 24)$ may give RYPC from 50 to $60 \%$ (Table 6 and Fig. 6).
Table 5. Quality index $q_{i}$ and total IWQI for different parameters of the groundwater's

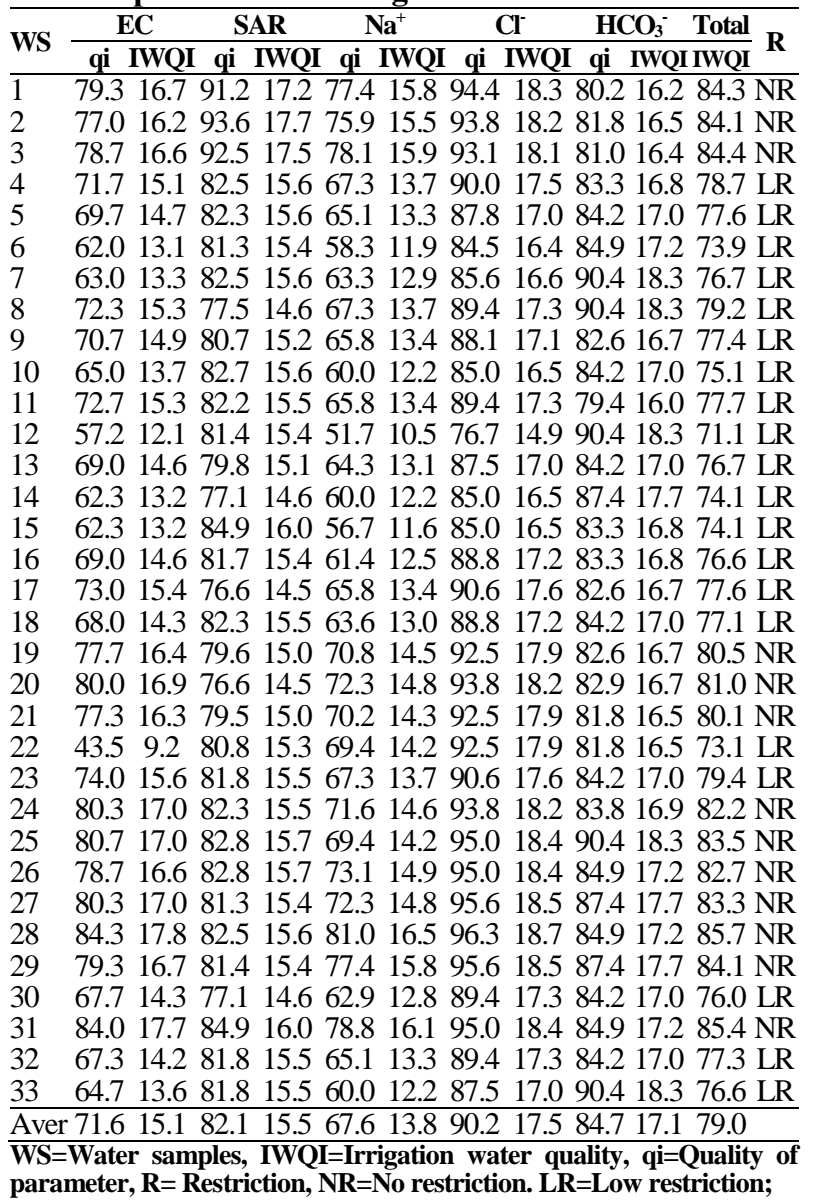
parameter, $R=$ Restriction, $N R=$ No restriction. $L R=L o w$ restriction;

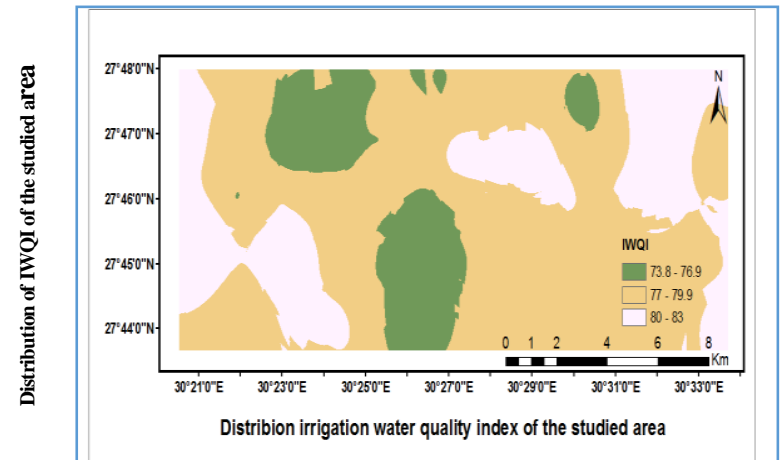

Fig. 5. IWQI for the studied groundwater samples Relative Yield Potential for Crop (RYPC)

For corn crop, data presented in Table 6 reveal that the values of relative yield potential ranged between 0.0 to $81 \%$ with an average of $33 \%$. The (RYPC) values of about $12 \%$ (exceed $75 \%$, while $42 \%$ of groundwater samples are of zero (RYPC) values. The best result are those of sugar beet crop, since $94 \%$ of the investigated groundwater samples may result in $100 \%$ of relative yield potential, whereas groundwater samples Nos. 14 and 32 will give zero (RYPC) values.

The values of relative yield potential for wheat ranged from 0.0 to $100 \%$ with an average of $73.5 \%$, Table 6. According to the (RYPC) values of wheat crop, $12.1 \%$, representing 4 groundwater samples have zero RYPC value i.e. will not give any yield when used for irrigation and about $9.0 \%$ will result in relative yield potential for wheat less than $50 \%$, whereas eight samples will give RCYP from 52 to $88 \%$ whereas eighteen water samples will give $100 \%$ of RYPC. 


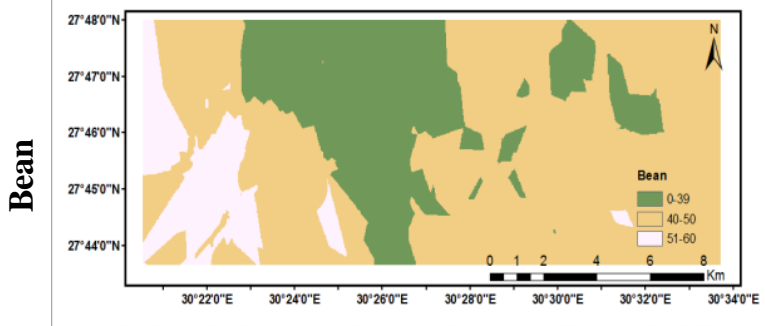

Relative yeild of Bean according to irrigation water quality and soil salinities

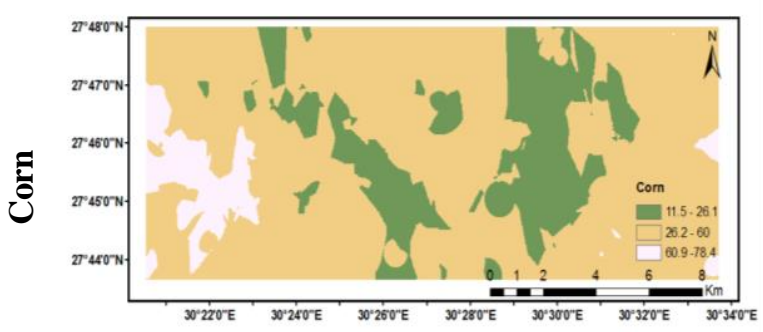

Relative yeild of corn according to irrigation water quality and soil salinities

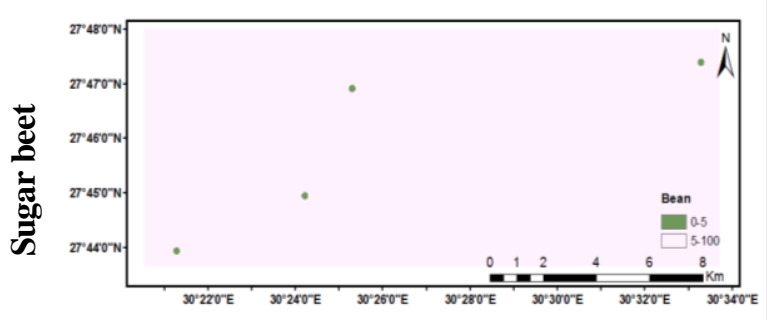

Relative yeild of Sugar beet according to irrigation water quality and soil salinities

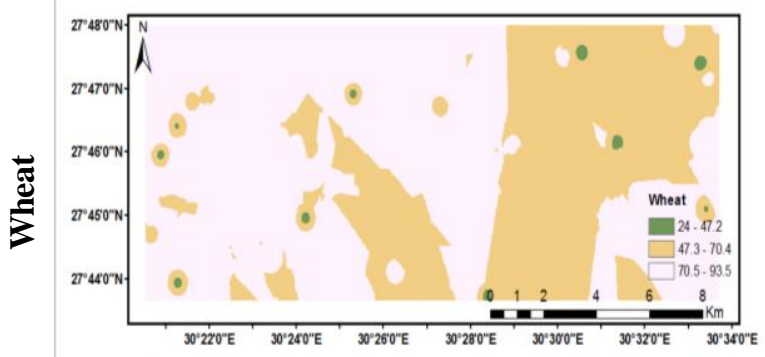

Relative yeild of Wheat according to irrigation water quality and soil salinities

Fig. 6. Relative yield for selected crops based on Hoffman equation

Table 6. The relative yield potential for selected crops

\begin{tabular}{lccccccccc}
\hline No. Bean Corn & $\begin{array}{c}\text { Sugar } \\
\text { beet }\end{array}$ & Wheat No. Bean Corn & $\begin{array}{c}\text { Sugar } \\
\text { beet }\end{array}$ & Wheat \\
\hline 1 & 52.4 & 78.0 & 100.0 & 100.0 & 18 & 0.0 & 0.0 & 100.0 & 18.7 \\
2 & 35.8 & 67.5 & 100.0 & 100.0 & 19 & 23.2 & 59.4 & 100.0 & 100.0 \\
3 & 49.8 & 76.4 & 100.0 & 100.0 & 20 & 0.0 & 0.0 & 100.0 & 0.0 \\
4 & 0.0 & 0.0 & 100.0 & 52.1 & 21 & 48.4 & 75.5 & 100.0 & 100.0 \\
5 & 0.0 & 0.0 & 100.0 & 55.2 & 22 & 17.1 & 55.5 & 100.0 & 100.0 \\
6 & 9.4 & 50.6 & 100.0 & 100.0 & 23 & 9.9 & 50.9 & 100.0 & 100.0 \\
7 & 0.0 & 41.6 & 100.0 & 96.1 & 24 & 58.0 & 81.6 & 100.0 & 100.0 \\
8 & 0.0 & 27.7 & 100.0 & 87.9 & 25 & 47.4 & 74.8 & 100.0 & 100.0 \\
9 & 7.5 & 49.4 & 100.0 & 100.0 & 26 & 0.0 & 38.9 & 100.0 & 94.5 \\
10 & 42.0 & 71.4 & 100.0 & 100.0 & 27 & 0.0 & 38.9 & 100.0 & 94.5 \\
11 & 0.0 & 0.0 & 100.0 & 0.0 & 28 & 0.0 & 0.0 & 100.0 & 47.3 \\
12 & 31.6 & 64.8 & 100.0 & 100.0 & 29 & 0.0 & 0.0 & 100.0 & 47.3 \\
13 & 0.0 & 0.0 & 100.0 & 66.6 & 30 & 0.0 & 0.0 & 100.0 & 66.5 \\
14 & 0.0 & 0.0 & 0.0 & 0.0 & 31 & 0.0 & 0.0 & 100.0 & 66.5 \\
15 & 0.0 & 0.0 & 100.0 & 69.3 & 32 & 0.0 & 0.0 & 0.0 & 0.0 \\
16 & 0.0 & 0.0 & 100.0 & 69.5 & 33 & 5.9 & 48.3 & 100.0 & 100.0 \\
17 & 0.0 & 37.2 & 100.0 & 93.5 & & & & & \\
\hline
\end{tabular}

The aforementioned selected crops can be arranged according to the calculated RYPC values in the following descending order: sugar beet, wheat, corn and bean.

\section{CONCLUSION}

Groundwater is the only resource for irrigation in the study area. The quality of the studied ground waters samples indicated that $100 \%$ of groundwater samples are permissible for irrigation purposes based on EC, SAR and RSC. On the other hand, $94 \%, 85 \%, 63 \%$ of ground water samples classified as good order based on $\mathrm{Na} \%, \mathrm{Cl}$ and KR parameters, respectively. As for multi index (IWQI) the results showed that about $21 \%$ of the groundwater samples belong to No Restriction (NR) while about $79 \%$ from the total samples belong to the Low Restriction (LR) category. All samples in multi index are suitable for irrigation, but some of the studied groundwater samples belong to the Low Restriction (LR) can be used successfully for irrigation, but they are in need for special salinity control management involving the addition of leaching requirements and selecting salt tolerant plants. The relative yield percent according to the RYPC values is: (94\%), (74\%), (33\%) and (13\%) for sugar beet, wheat, corn and bean respectively.

\section{REFERENCES}

Adams, S., Titus, R., Pietersen, K., Tredoux, G., Harris, C., 2001.Hydrochemical characteristics of aquifers near Sutherland in the Western Karoo, South Africa. Journal of Hydrology, 241, 91-103. doi: 10.1016/S0022-1694(00)00370-X

Aghazadeh, N. and Mogaddam, A., 2010. Assessment of Groundwater Quality and its Suitability for Drinking and Agricultural Uses in the Oshnavieh Area, Northwest of Iran, Journal of Environmental Protection, 1 (1), 30-40.doi:10.4236/jep.2010.11005.

Andrade, E., Palacio, H.A.Q., Souza, I.H., Leao, R.A. and Guerreio, M.J. (2008) Land Use Effects in Groundwater Composition of an Alluvial Aquifer by Multivariate Techniques. Environmental Research, 106, 170-177. doi: 10.1016/j.envres.2007.10.008

APHA 1995.Standard Methods for the examination of water and wastewater (19th edn). Washington: American Public Health Association.

Appelo, C.A.J., Postma, D. 2005. Geochemistry, Groundwater and Pollution. 2nd Edition, Balkema, Rotterdam. doi: 10.1201/9781439833544

Aragüés, R., Medina, E.T., Zribi, W., Clavería, I., ÁlvaroFuentes, J., Faci, J., 2015. Soil salinization as a threat to the sustainability of deficit irrigation under present and expected climate change scenarios.IrrigSci 33, 67-79. doi:10.1007/s00271-014-0449-x

Arshid, J., Aasimah, T., Yousuf, A.R., Akbar, M. Aabid, H.N. 2011.Geochemistry and irrigation quality of groundwater along River Jhelum in South Kashmir, India.Recent Res. In Sci. and Tech. 3(6): 57-63.

Arveti N., Muralidhar, P., Sreedhar, Y., 2016. Hydrogeochemistryand Groundwater Quality Assessment of Rapur Area, Andhra Pradesh, South India. Journal of Geoscience and Environment Protection, 4, 88-99. doi: 10.4236/gep.2016.44012

Asadi, S.S., Vuppala, P., Reddy, M.A. 2007. Remote sensing and GIS techniques for evaluation of groundwater quality in municipal corporation of Hyderabad (Zone-V), India. Int $\mathrm{J}$ Environ Res Public Health. 4(1):45-52.

Ayers, R.S., Westcot, D.W. 1985.Water Quality for Agriculture.FAO. Irrigation and Drainage Paper No. 29. Food and Agriculture Organization of the United Nations, Rome, pp. 1-117.

Bauder, T. A., Waskom, R. M. Davis, J. G. 2007.Irrigation water quality criteria. Extension fact sheet No. 0.506, Colorado State University. 15p. 
Bunani, S., Yörükoğlu, E., Yüksel, Ü, Kabay, N., Yüksel, M., Sert, G., 2015. Application of reverse osmosis for reuse of secondary treated urban wastewater in agricultural irrigation.Desalination 364, 68- 74.doi: 10.1016/j.desal.2014.07.030

Deshpande, S.M., Aher, K.R. 2012.Evaluation of groundwater quality and its suitability for drinking and agriculture use in parts of Vaijapur, District Aurangabad, MS, India. Research Journal of Chemical Sciences, 2 (1), 25-31.

Freeze, R. A., Cherry, J. A., 1979.Groundwater. Englewood Cliffs: Prentice Hall, pp. 604.

Harkins .R.D., 1974. An objective water quality Index, J. water Poll. Cont. Fed. 3: 589-591.

Holanda and Amorim 1997.Management and Control Salinity and Irrigated Agriculture Water, CongressoBrasileiro de Engenharia setting,

Horton, R. K. 1965. An index number system for rating water quality.Journal-Water Pollution Control Federation. 37: 300-305.

Hounslow, A.W., 1995) Water Quality Data: Analysis and Interpretation. CRC Press LLC, Lewis Publishers, BocaRaton.

Jafar Ahmed, A., Loganathan, K., Ananthakrishnan, S. 2013. A Comparative Evaluation of Groundwater Suitabilityfor Drinking and Irrigation Purposes in Pugalur Area, Karur District, Tamilnadu, India. Scholar Research Library, 5,213-223.

Jalali M., 2008. Effect of sodium and magnesium on kinetics of potassium release in some calcareous soils of western Iran.Geoderma 145:207-215. doi:10.1016/j.geoderma.2008.03.005

Kelley, W.P. 1940. Permissible composition and concentration of irrigation waters, Proc. ASCE, 66, 607.

Läuchli, A, Epstein, E., 1990.Plant responses to saline and sodic conditions. In: Tanji KK (ed.) Agricultural salinity assessment and management. ASCE New York. ASCE manuals and reports on engineering practice No, 71, pp.113-137

Liu, S., Tang, Z., Gao, M., Hou, G., 2017. Evolutionary process of saline-water intrusion in Holocene and Late Pleistocene groundwater in southern Laizhou Bay.Science of The Total Environment607-08, 586-599 doi:10.1016/j.scitotenv.2017.06.262

Maas, E.V. and Hoffman, G.J., 1977 Crop salt tolerancecurrent assessment. Journal of the Irrigation and Drainage Division, 103, 115-134.

Mass, E. V. 1990. Crop Salt Tolerance. In: Agricultural Salinity Assessment and Management Manual. K.K. Tanji (ed.). ASCE, New York. pp 262-304.
Meireles, A., Andrade E.M., Chaves L., Frischkorn, H. and Crisostomo, L.A., 2010. A new proposal of the classification of irrigation water, Revista Ciencia Agronomica, 41 (3), 349 - 357. doi:10.1590/ S1806-66902010000300005

Paliwal, K.V. 1972. Irrigation with saline water (p. 198) Monogram No. 2 (New series). IARI, New Delhi.

Prasad, A., Kumar, D., Singh, D.V. 2001. Effect of residual sodium carbonate in irrigation water on the soil sodication and yield of palmarosa (Cymbopogonmartinni) and lemongrass (Cymbopogonflexuosus). Agricultural Water Management50 (3), 161-172. doi: 10.1016/S03783774(01)00103-2

Raghunath, H.M. 1987. Groundwater. Wiley Eastern Ltd., Delhi.

Roy, K, Ansari, S., Karim, R., Das, R., Mallick, B., Gain, AQ.K., 2015. Irrigation water quality assessment and identification of River pollution sources in Bangladesh: Implications in policy and panagement. Journal of Water Resource and Hydraulic Engineering, 4 (4), 237-248. doi:10.5963/JWR HE0404001

Sulieman, M. , Ibrahim, I. and Elfaki, J. (2016) Genesis and Classification of Some Soils of the River Nile Terraces: A Case Study of Khartoum North, Sudan. Journal of Geoscience and Environment Protection, 4, 1-16. doi: 10.4236/gep.2016.43001.

Sutharsiny, A., Pathmarajah, S., Thushyanthy, M. and Meththika, V. 2012.Characterization of irrigation water quality of Chunnakam Aquifer in Jaffna Peninsula. Tropical Agricultural Research, 23 (3), 237-248. doi: 10.4038/tar.v23i3.4661

Tiwari, T.N., Mishra, M.A., 1985. A preliminary assignment of Water Quality Index of major Indian rivers. Indian J Environ Prot. 5, 276-279.

USSL.1954) Diagnosis and Improvement of Saline and Alkali Soils.United State Salinity Laboratory, Agricultural Handbook, USDA, No. 60, pp. 160.

Waqed, H. 2014. Assessment of groundwater quality in UMM ER Radhuma Aquifer (Iraqi Western Desert) by integration between Irrigation Water Quality Index and GIS. J. Babylon Uni. Engineering Sciences 1 (22), 201-217

Wilcox, L. 1955. Classification and uses of irrigation waters.USDA Circular No. 969, Washington, DC.

Zeng, C., Liu, Z., Zhao, M., Yang, R. 2016.Hydrologicallydriven variations in the karst-related carbon sink fluxes: Insights from high-resolution monitoring of three karst catchments in Southwest China.Journal of Hydrology 533, 74-90. doi: 10.1016/j.jhydrol. 2015.11.049

\section{تقيم جودة المياه الجوفية لأغراض الري بمنطقة غرب المنيا إبراهيم محمد عبد العزيز حجازئ 1.

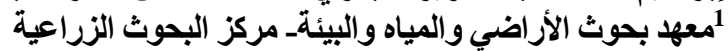

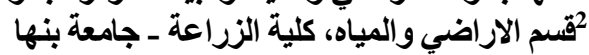

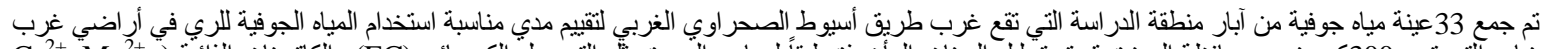

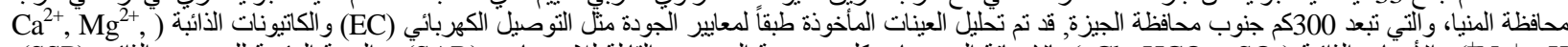

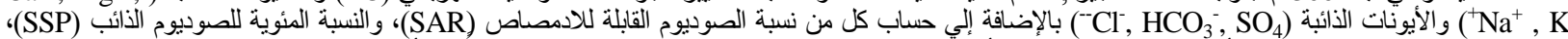

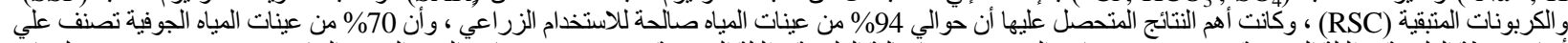

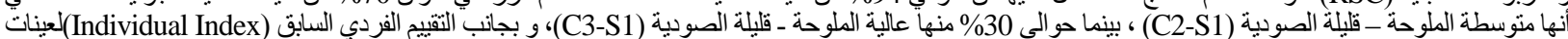

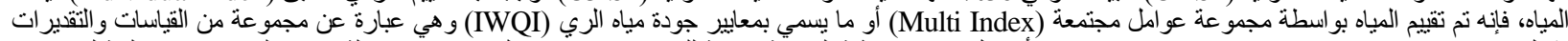
تشمل (EC, SAR, Na \%, Cl and HCO He

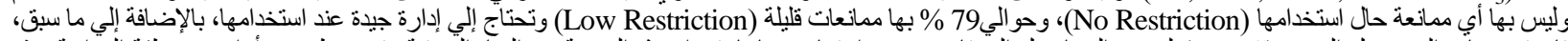

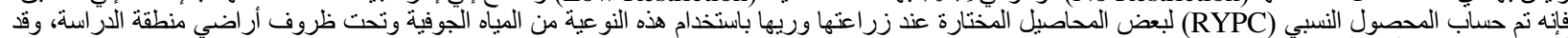

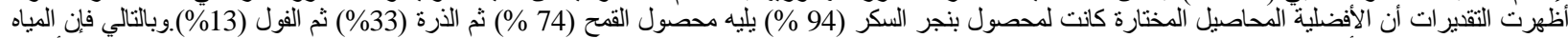

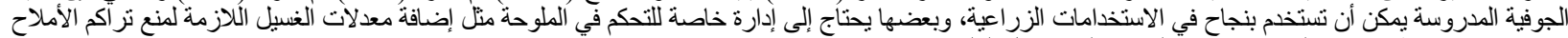
و إبعادها خارج منطقة انتشار الجذور واختنيار النباتات التي تنحمل الملوحة. 